\title{
ON CO-INCIDENCE OF PLASTIC (POLYTHENE) GRAINS IN THE GIZZARD OF SEMI-WILD (FREELY INHABITING) COMMON ROCK PIGEON, Columba livia intermedia, Linnaeus, 1758, IN BIRATAGAR, NEPAL
}

\begin{abstract}
Plastic (polythene) granules of industrial use was obtained in the gizzard of semi-wild (freely inhibitory i.e., not captivated) common rock pigeon. Columba, livia intermidia Linnaeus, 1758, inhabiting at an altitudinal range of 72-80 $m$ in Biratnagar, Nepal while its gizzard was cut open to remove internal content. Since then, gizzard of about 36 such pigeon were cut open to trace granules. In the gizzard of 19 birds, plastic granules were obtained. Such occurrence may be due to hunger or confusion or both or due to overwhelmingly prevalent situation of the present environment.
\end{abstract}

Rakesh Prasad Bhagat

Key Words: co-incidence, plastic grains, semi-wild pigeon. Columba livia intermedia, Biratnagar.

\section{INTRODUCTION}

Columba livia intermedia Linnaeus, 1758, commonly called pigeon or common rock pigeon or blue rock pigeon or common blue rock pigeon or Indian rock pigeon and locally Parewa is a residential bird of Biratnagar, Morang District, Koshi Zone, Eastern region of Nepal, inhabiting here at an altitude of 72$80 \mathrm{~m}$. It is a bird of domestication and is reared at large (pigeon farming) or family scale because of its usefulness in human consumption as meat. Pigeons are reared in aerated space or in pen of required size. Generally, pigeons do not escape or flee from the pen, but if, some notorious ones get a change to do so, they may flee anywhere in search of protected areas and good shelters. So as to lead an independent (free) life. For such pigeons, protected area and good shelter may be that place where no men can interfere them. Shelter selected by them is often located at considerable height so that they can live in prefect freedom in ledges fissures and holes of old building and wells but they prefer to live in big buildings, go downs, markets, temples, mosques, churches, tombs, office building, but stations, etc. In this way, to some extent they become safe being out of reach of man. Such pigeons, as they inhabit freely and lead an independent life, may be called semi-wild pigeons. Semi-wild pigeons not only come from domesticated stock via escaping but also from wild stock. But in semi-wild state, they have to depend on food collected by themselves as compared to domesticated pigeon that obtain food by their keeper (rearer).

Mr. Bhagat is Lecturer in Science at Mahendra Morang Adarsha Multiple Campus, Biratnagar, Nepal. 
ON CO-INCIDENCE OF PLASTIC ...

The alimentary canal of pigeon is a long coiled tube with anterior most mouth and posterior most cloacal aperture. If comprises foregut or stomodaeum (mouth, buccal cavity, pharynx, oesophagus, crop and stomach), midgut or mesenteron (duodenum and ileum) and hindgut or proctodaeum (rectum and cloaca).

The stomach which constitutes an important part of foregut of the bird is differentiated into an anterior proventricalus and posterior gizzard.

The gizzard of pigeon which represent the pyloric stomach of other animals is a thick-walled muscular structure bi-convex in a shape and with narrow lumen. The lumen is lined by an epithelium, which is thick, tough, horny and green or yellow in colour.

The cavity of gizzard always contains small stones or grit swallowed by the bird. These stones help the gizzard in grinding the food mechanically.

\section{LITERATURE REVIEW}

C. livia intermedia. L., 1758, the blue rock pigeon, is mainly a seed eating bird. It's animal diet consist of snails and smell creatures. It habitually picks up small pebbles which in the gizzard aid in the grinding process (Nigam, 1973).

Pigeons are vegetarians feeding on grains, pulses, seeds of fruits and grasses. Sometimes they feed diet consists of snails and slugs probably mistake for seeds. They regularly leave their places of retreats and settings during morning and evening into flocks to plunder the nearly field (Jordan \& Verma, 1977).

Food of the blue rock pigeon chiefly comprised seeds, grains, drupes, etc. (Ali \& Ripley, 1994). During the process of digestion, food from the crop of pigeon enters the gizzard where mechanical breakdown of food takes place by muscular contraction of gizzard wall and grinding action of small stones inside the lumen of gizzard (Jordan \& Verma, 1977).

\section{MATERIAL \& METHODS}

Once when the gizzard of a common rock pigeon, Columba livia intermedia, L. 1758, inhabiting in semi-wild state was found to contain plastic grains of industrial use, instead of small stones or grit, the way towards further investigation was supposed to be opened. Since then semi-wild pigeons were dissected. Collection of semi-wild pigeons and analysis of gizzard's content were done for a period of 1 year starting from March 2001 to February, 2002.

Identification of the bird, interpretation of its food, discussion about the gizzards content and other necessary details and explanation were followed as given and described by Ali (1961), Ali \& Ripley (1963-64, 1994), Flemming (1981-82), Flemming and Flemming (1984), Grzimek (1973), Jordan \& Verma (1977), Majumdar (1990), Mierow (1988), Nigam (1973), Ripley (n.d.)

\section{OBSERVATION}

One while the gizzard of the semi-wild pigeon inhabiting at Shankarpur, Ward No. 3, of Biratnagar was cut open, the content inside it was found to be different instead of small stones or grit. The content was analyzed and found to contain small, spherical, compressed and creamy-white grains depressed in the centre. These grains 
were identified to be plastic (Polythene) grains of industrial use. There grains are utilized industrially to prepare polythene bag, pipe, container, etc.

The coincidence of the presence of plastic (Polythene) grain of industrial use in the gizzard of semi-wild pigeon was noticed on Thursday, March, 2008. 2001 while its gizzard was cut open. Since then from March, 2001 to February, 2002, two, three or four pigeons were dissected every month to confirm the internal content in the gizzard. Altogether 36 such pigeons were dissected within the mention periods. When the content of their gizzard was analyzed: it was found that 19 pigeons were having plastic (Polythen) granules in their gizzard (Table-1).

\section{RESULTS DISCUSSION}

At the age of one or one $\&$ half months, pigeons learn to fly, feed and protect themselves. Their parents also help them to do so by teaching or giving instruction. When they are taught, they have to follow the instruction given by their parents, during which they try to swallow some stones or grit as a natural requirement (Nigam, 1973). But instead of swallowing grit or stones, they swallowed plastic granules. The reason behind such coincidence might be less availability of or less accessibility towards small stones or girt in the vicinity in which there pigeons inhabit or easy availability of or easy accessibility toward small stones or grit like plastic granules (there are 2 plastic industries in the surroundings of ward no. 3 Biratnagar where these pigeons live freely) that looks fine in every respect in comparison to stones or grit.

Another reason of such coincidence might be due to scarcity of food. When food for these semi-wild pigeon scarce then to compensate their hunger they might have swallowed/consumed plastic granules.

Still another reason might be that when hungry birds were searching for food, plastic granules that more or less resembled cereal grains confused them. So, in confusion, they might have swallowed plastic granules. Same type of argument could also be given. When birds were searching for stones or grit, plastic granules that more or less resembled stones or grit, plastic granules that more or less resembled stones or grit confused them. Therefore, in confusion they might have swallowed plastic, granules, according to Jordan \& Verma (1977). They can feed on insects, snails and slugs probably mistaken for seeds.

Hence, coincidence of plastic granules in the gizzard was due to overwhelming situation, the birds were facing in their habitat. It may be due to hunger or due to confusion or may be the combination of hunger and confusion or due to the reason created by new environment in which everything is changing.

Table-1

Table showing obtaining of the plastic (Polythene) granules

\begin{tabular}{|c|c|c|c|c|c|c|c|c|c|c|c|c|c|}
\hline $\begin{array}{l}\text { Months } \\
\text { Pigeons }\end{array}$ & $\sum^{\text {Jँ }}$ & 䒺 & 无 & $\Xi$ & $\Xi$ & $\stackrel{000}{2}$ & 苟 & $\overline{0}$ & z & ஹू & $\underset{\mathrm{E}}{\text { ( }}$ & 包 & 䒿 \\
\hline Dissected & 2 & 4 & 3 & 3 & 4 & 3 & 3 & 4 & 2 & 2 & 4 & 2 & $\overrightarrow{36}$ \\
\hline $\begin{array}{l}\text { Plastic } \\
\text { granules } \\
\text { obtained }\end{array}$ & 1 & 2 & 1 & 2 & 1 & 2 & 2 & 1 & 2 & 1 & 2 & 2 & 19 \\
\hline
\end{tabular}




\section{WORKS CITED}

Ali, S. \& Ripley, D. 1963-64. Hand book of the bird of India and Pakistan. Vol. 1-10 (Species description \# 516).

------. 1994. A pictorial guide to the birds of the Indian sub continent. Bombay Natural History Society. Centenary publication, Oxford University Press. Bombay Delhi Calcutta Madras. 27. 177 p., 48 (1) p. 1.

--------, n.d.. The Book of Indian Birds. Bombay: Natural History Society.

Fleming, R.L. Jr. 1981-82.: Birds. In: Wild in Beautiful. (Ed.) Majupuria. T.C.S. Devi, Llitpur, Colony. Lashkar, Gwalior, M.P. India. 280 p.

Fleming, R.L. sr. \& Fleming, R. L. Jr. 1984. Birds of Nepal (with reference to Kashmir and Sikkim). Natural Himalayas. P.O. Box \# 229. Kathmandu, Nepal, 102. 103 p.

Grzimek, h.c. Bernhard Dr. 1968. Birds II. Grzimeki's Animal Life Encyclopedia. Van Nostrand Reinhold company, New York. Cincinnati Toronto London. Melbourne. Vol. 8. 1 (Fig.) 253-256).

Jordan, E.L. \& Verma, P.S. 1977. Chordate Zoology \& Animal Physiology. S. Chand \& Company Ltd. Rnanagar, New Delhi 110055. 426. 466-472 p.

Majumdar, M. 1990. Birds. In: Wildlife wealth of India (Resource \& Management) (Ed.) Majupuria. T.C. Teepress Service. L.P. 487/42. Soi Wattanslip Pratunam. Bankok. 10400. Thailand. 283 p.

Mierow, D. 1988. Birds of the Central Himalayas. An ecological Approach. (Ed.) Majupuria. T.C. Craftsman press. Bankok. Thailand. Tel. \# 2533005. 253-3298. 190. 191 p.

Nigam, H.C. 1973. Zoology of Chordates. S. Nagin \& Company. Educational Publisher. Jallander. Delhi. 176. 405. 406. p.

Ripley, S.D. n.d.. A synopsis of the Birds or India and Pakistan. $2^{\text {nd }}$ edition.

Robert L. Fleming Sr. Robert Flemming, L. Jr. and Bangdel, L. S. (1976): Birds of Nepal with reference to Kashmir and Sikkim. R. L. Flemming Sr. \& Jr., Box 229. Kathmandu, Nepal. Species description\# 517. 102.103 p. 